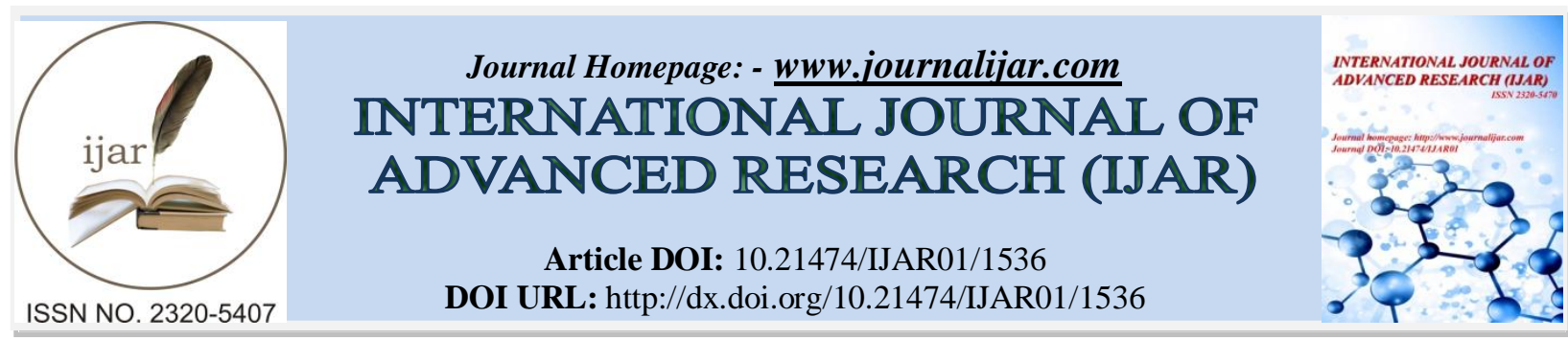

RESEARCH ARTICLE

\title{
COMPARISON OF SERUM CALCIUM AND ZINC LEVELS IN NORMAL PREGNANCY AND PREGNANCY WITH PRE-ECLAMPSIA.
}

\section{Kamaljeet Kaur ${ }^{1}$, Harpreet Kaur ${ }^{3}$, Premjeet Kaur ${ }^{1}$, Chittranjan Vij ${ }^{2}$, Gurdeep Kaur Bedi ${ }^{2}$ and Paramjit Kaur $^{2}$.}

1. Government Medical College \& Hospital, Chandigarh.

2. Government Medical College, Patiala.

3. Maharishi Markandeshwar Medical College \& Hospital, Solan.

\section{Manuscript Info}

[..........................

Manuscript History

Received: 12 July 2016

Final Accepted: 12 August 2016

Published: September 2016

Key words:-

calcium, zinc, pre-eclampsia.

\section{Abstract}

Research Question:- To compare and correlate serum calcium and serum zinc levels of pre-eclamptic and normotensive pregnant females.

Study Design:- Case control study

Methodology:- This study was conducted in randomly selected 100 pregnant females. The study group was further divided into two groups which included 50 pregnant females with pre-eclampsia at gestation of 20 weeks or more as cases and control group which included 50 normotensive pregnant females.

Results:- Both serum calcium and zinc levels were significantly low in the study group. Reduction in serum levels of calcium and zinc during pregnancy might be associated with risk of pre-eclampsia, and supplementation of these elements to diet during pregnancy may prevent pre-eclampsia.

Copy Right, IJAR, 2016,. All rights reserved.

\section{Introduction:-}

Pre-eclampsia is one of the major complication of pregnancy associated with increased maternal and infant mortality and morbidity. ${ }^{[1]}$ According to The National High Blood Pressure Education Program (NHBPEP) Working Group , Pre-eclampsia is characterized by development of BP $140 / 90 \mathrm{mmHg}$ or greater after 20 weeks gestation in a women with previously normal blood pressure and with proteinuria more than $0.3 \mathrm{~g}$ protein in 24 -h urine specimen. ${ }^{[2]}$ Calcium plays an important role in the function of vascular smooth muscles. Decrease in serum calcium concentration leads to an increase in the intracellular calcium. ${ }^{[3]}$ Increase of cellular calcium causes constriction of smooth muscles in blood vessels and increase of vascular resistance and therefore, causes increased blood pressure. ${ }^{[4]}$

Oxidative stress or excessive lipid peroxidation may act as an important factor in the pathogenesis of pre-eclampsia. Zinc is required for the proper functioning of antioxidant enzymes which protect injuries from free radicals. Deficiency of zinc may decrease the effect of antioxidant potential of cells leading to increase in blood pressure $^{[1][]^{[j] 6]}}$ Towards the end of normal pregnancy, maternal serum zinc level declines due to increased foetal demands, haemodilution, decrease in serum albumin levels and hormonal changes, as well as shifting of zinc from plasma to red blood corpuscle can also cause decrease in serum zinc levels in pregnant women. ${ }^{[7]}$ The present study

Corresponding Author:- Kamaljeet Kaur.

Address:- Government Medical College \& Hospital, Chandigarh. 
was carried out to compare and correlate serum calcium and serum zinc levels of pre-eclamptic and normotensive pregnant females.

\section{Materials \& methods:-}

The present study was conducted in the Department of Biochemistry and Department of Obstetrics and Gynecology, GMC, Patiala after getting ethical clearance from ethical committee. Study group comprised of 100 pregnant females. The study group was further divided into :

Cases - 50 pregnant females with period of gestation more than 20 weeks with pre-eclampsia, diagnosed by National High Blood Pressure Education Program (NHBPEP) criteria.

Controls - 50 pregnant females with period of gestation more than 20 weeks who were normotensive.

Blood samples under all aseptic conditions were obtained by venepuncture from all the patients as well as controls after taking their written consent.

\section{Inclusion Criteria:-}

$>$ Pregnant females with POG $>20$ weeks with pre-eclampsia.

\section{Exclusion criteria:-}

$>$ All cases of essential hypertension or chronic hypertension due to any other cause. Any associated renal, hepatic, neurological disorders not due to pregnancy induced hypertension. Associated molar pregnancy or twin pregnancy.

Apart from routine investigations serum calcium and zinc levels were estimated in all cases and controls. The estimation was done by colorimetric methods on Erba Chem 5 semi-autoanalyzer.

Serum calcium was done by ortho-cresolphthalein complexone method ${ }^{[8]}$ and serum zinc was done by Nitro PAPS method. ${ }^{[9]}$

\section{Results:-}

The mean age of the Pregnant females in the study group was $24.62 \pm 4.421$ years and in the control group was $25.54 \pm 4.107$ years.

Table No.1:- Distribution of patients according to POG

\begin{tabular}{|c|c|c|c|c|}
\hline \multirow{2}{*}{ POG (wks) } & \multicolumn{2}{|c|}{ Cases } & \multicolumn{2}{c|}{ Controls } \\
\cline { 2 - 5 } & No. of cases & \%age & No. of cases & \%age \\
\hline $20-25$ & 4 & 8 & 17 & 34 \\
\hline $26-30$ & 8 & 16 & 10 & 20 \\
\hline $31-35$ & 29 & 58 & 16 & 32 \\
\hline$>35$ & 9 & 18 & 7 & 14 \\
\hline
\end{tabular}

The percentage of patients in the group 31-35 wks POG was 58\% showing the increased risk of pre-eclampsia in this period.

Table No.2:- comparison of biochemical parameters in the cases and control group.

\begin{tabular}{|c|c|c|c|c|c|}
\hline \multirow{2}{*}{$\begin{array}{l}\text { Mean } \pm \text { SD of the } \\
\text { parameter }\end{array}$} & \multicolumn{2}{|c|}{ Group } & \multirow{2}{*}{$\begin{array}{c}\mathrm{t} \\
\text { value }\end{array}$} & \multirow{2}{*}{$\begin{array}{c}\mathbf{P} \\
\text { value }\end{array}$} & \multirow{2}{*}{ Significance } \\
\hline & Cases & Controls & & & \\
\hline FBS $(\mathrm{mg} / \mathrm{dl})$ & $77.38 \pm 8.727$ & $74.88 \pm 7.976$ & 1.495 & 0.138 & NS \\
\hline Blood Urea $(\mathrm{mg} / \mathrm{dl})$ & $29.84 \pm 8.947$ & $24.34 \pm 3.740$ & 4.010 & $<0.001$ & HS \\
\hline S. Creatinine $(\mathrm{mg} / \mathrm{dl})$ & $1.112 \pm .2256$ & $1.002 \pm 0.1020$ & 3.142 & 0.002 & $\mathrm{~S}$ \\
\hline S. Uric acid $(\mathrm{mg} / \mathrm{dl})$ & $6.210 \pm 5.7636$ & $4.342 \pm 0.6383$ & 2.278 & 0.025 & $\mathrm{~S}$ \\
\hline AST (IU/l) & $55.61 \pm 51.69$ & $25.14 \pm 4.52$ & 4.153 & $<0.001$ & HS \\
\hline ALT(IU/l) & $50.06 \pm 52.30$ & $18.04 \pm 6.77$ & 4.293 & $<0.001$ & $\mathrm{HS}$ \\
\hline
\end{tabular}


Table 2 shows routine investigations done in both study and control group. Serum urea, creatinine and uric acid were significantly higher in cases as compared to controls ( $\mathrm{p}$ value $<0.05$ ). Serum ALT and AST levels were also significantly high in cases as compared to controls (pvalue <0.001). FBS was comparable in both cases and controls.

COMPARISON OF SERUM CALCIUM LEVELS IN STUDY AND CONTROL GROUP

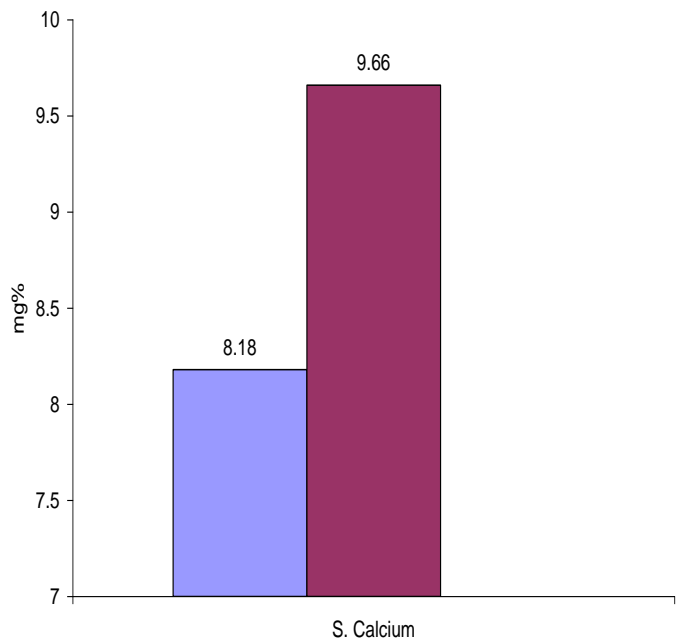

COMPARISON OF SERUM ZINC LEVELS IN STUDY AND CONTROL GROUP
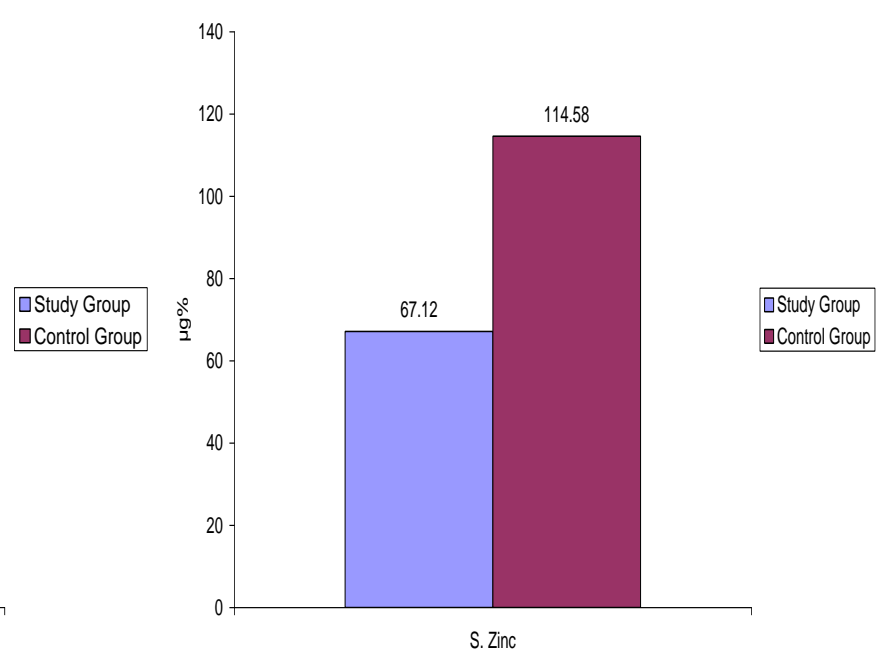

Figure 1(a)(b):- Comparison of serum calcium and zinc in study and control group.

Mean serum calcium levels were found to be $9.66 \pm 0.37 \mathrm{mg} / \mathrm{dl}$ in normal pregnancy and $8.18 \pm 0.24 \mathrm{mg} / \mathrm{dl}$ in preeclamptic group. The difference was found to be statistically significant ( $\mathrm{p}$ value $<0.05$ ) Also significantly decreased levels of serum zinc was found in pre-eclamptic females (67.12 \pm 8.05$)$ as compared to normal pregnant females $(114.58 \pm 123.34)$ ( $\mathrm{p}$ value $<0.05)$.

Figure 2 shows a positive correlation between serum calcium and zinc in study group which shows a decrease in both the parameters in pre-eclamptic females.

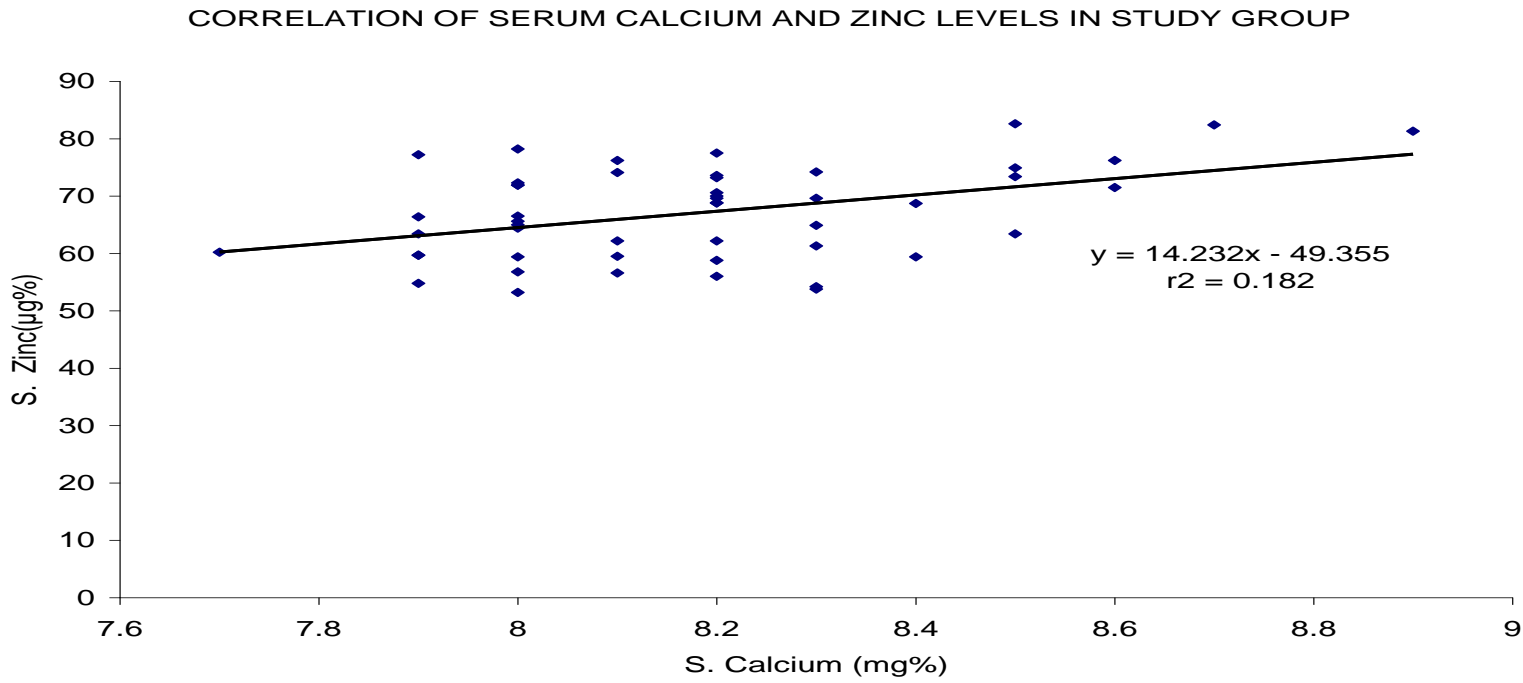

Figure 2:- correlation of serum calcium and zinc in study group. 


\section{Discussion:-}

About 600,000 women die because of delivery complications every year in the world and about $50 \%$ of these cases are due to risky pregnancies. ${ }^{[10]}$ As per the WHO recommendations, In populations where calcium intake is low, calcium supplements should be given for the prevention of pre-eclampsia in pregnant women particularly among those who are at higher risk of developing hypertension. ${ }^{[1]}$ In our study, decreased levels of serum calcium and zinc were seen in pre-eclamptic females as compared to normal pregnant females and the correlation between both the parameter was highly significant ( $p$ value $<0.05$ ). Similar results were found in a study by Jain et al. ${ }^{[1]}$ It has been widely accepted that there is a relationship between low serum calcium levels and pre-eclampsia. Study conducted by Malas et al suggests that maternal serum total calcium and parathyroid hormone are related to pre-eclampsia in pregnancy. ${ }^{[12]}$ Hofmyer et al in his study suggests that the calcium supplements play an important role during pregnancy in reducing risk of hypertension and pre-eclampsia. ${ }^{[13]}$ This effect was found more significant in those studies where participants had low calcium intake compared to that of where calcium intake was adequate. ${ }^{[13]}$ In another study, Trumbo et al suggested that the beneficial effects of calcium supplementation could only be useful in populations whose baseline calcium intake is inadequate. ${ }^{[14]}$

Among the essential trace element zinc is required for proper reproductive health and for optimal cellular function. ${ }^{\text {[5] }}$ Inadequate dietary intake of zinc has been reported in $82 \%$ of the pregnant women worldwide. Decrease in serum zinc concentrations have been found to be related to pre-eclampsia. ${ }^{[15]}$ In our study mean serum zinc levels were found to be decreased significantely in pre-eclamptic females as compared to normotensive females. In a similar study by Gupta et al, plasma zinc levels were also significantly low in severe pre-eclampsia and eclampsia while the erythrocyte zinc levels showed no significant change. ${ }^{[16]}$ Kangal et al found low levels of maternal copper and zinc related to pre-eclampsia. ${ }^{[17]}$ Nutrients can modulate oxidative stress by affecting free radicals or antioxidants. ${ }^{[18]}$ Under increased oxidative stress, excessive lipid peroxidation, vasospasm caused by the imbalance of vasodilators and vasoconstrictors may progress towards the development of pre-eclampsia. ${ }^{[1][4]}$ Selina et al concluded that the deficiency of calcium and zinc in pre-eclamptic women were related to their inadequate dietary intake and this deficiency could be a risk factor for development of high blood pressure and pre-eclampsia. ${ }^{[19]} \mathrm{He} \mathrm{L} \mathrm{et} \mathrm{al}^{[20]} \mathrm{Kumari}$ $\mathrm{B}^{[21]}$ and Vafaei $\mathrm{H}^{[22]}$ also suggested the role of serum calcium and zinc in pre-eclampsia in their studies. But according to K Vidhya serum calcium and zinc deficiency cannot be pinpointed as the sole factors for the etiology of pre-eclampsia but they have a definite role in the development of pre-eclampsia ${ }^{[23]}$

\section{Conclusion:-}

Low levels of serum calcium and zinc have been found to be involved in development and pathogenesis of preeclampsia. Hence it is suggested that these investigations should be an integral part of the routine workup in early pregnancy for timely recognition and intervention in pre-eclampsia. In the light of the reduction in the concentration of serum calcium and zinc, dietary supplementation or direct replacement therapy of these elements is suggested for women with pre-eclampsia.

\section{Refrences:-}

1. Jain S, Sharma P, Kulshreshtha S, Mohan G and Singh S. The Role of Calcium, Magnesium, and Zinc in PreEclampsia. Biological Trace Element Research 2009;133:162-170.

2. Working Group report of the National High Blood Pressure Education Program on High Blood Pressure in Pregnancy. Am J Obstet Gynecol 2000;183(1):S1-S22.

3. Indumati K, Kodliwadmath MV and Sheela MK. The Role of serum Electrolytes in Pregnancy induced hypertension. Journal of Clinical and Diagnostic Research 2011; 5(1): 66-69.

4. Sukonpan K, Phupong V. Serum calcium and serum magnesium in normal and pre-eclamptic pregnancy.Arch Gynecol Obstet. 2005; 273:12-6.

5. Ashraf M, Nasarullah M, Salam A, Khurshid R, Ahmed Z. Maternal serum zinc concentration in gravidae suffering from preeclampsia. A.P.M.C. 2007; 1(1): 24-27.

6. Nourmohammadi I, Akbaryan A, Fatemi Sh, Meamarzadeh AR Nourmohammadi . Serum zinc concentration in Iranian preeclamptic and normotensive pregnant women. Middle East J. Fam. Med. 2008; 6(4): 30-32.

7. Groenen PM, Roes EM, Peer PG et al. Myo-inositol, glucose and zinc concentrations determined in the preconceptional period, during and after pregnancy. Eur J Obstet Gynecol Reprod Biol 2006;127:50-5.

8. Zak B, Epstein E and Baginski ES. Review of calcium methodologies, Annals of clinical and laboratory science 1975;5:195-215.

9. Makino T. Clin Chem. Acta 1991;197:209-220. 
10. Kumru S, Aydin S, Simsek M, Sahin K, Yaman M, Ay G . Comparison of serum copper, zinc, calcium and magnesium levels in preeclamptic and healthy pregnant women. Biol Trace Elem Res 2003;94(2):105-12.

11. WHO Guidelines: Calcium supplementation in pregnant women. Geneva, World Health Organization; 2013:updated 2016.

12. Malas NO, Shurideh ZM. Does serum calcium in pre-eclampsia and normal pregnancy differ? Saudi Med J 2001; 22 (10): 868-871.

13. Hofmeyr GJ, Atallah AN, Duley L: Calcium supplementation during pregnancy for preventing hypertensive disorders and related problems. Cochrane Database Syst Rev. 2006, 3: CD001059.

14. Trumbo PR, Ellwood KC: Supplemental calcium and risk reduction of hypertension, pregnancy-induced hypertension, and preeclampsia: an evidence-based review by the US Food and Drug Administration. Nutr Rev. 2007, 65 (2): 78-87.

15. Pathak P, Kapoor SK, Kapil U, Dwivedi SN. Serum magnesium level among pregnant women in a rural community of Haryana state. India. Eur. J. Clin. Nutr. 2003; 57: 1504- 06.

16. Gupta S, Jain NP, Avasthi K, Wander GS. Plasma and Erythrocyte Zinc in Pre-eclampsia and its Correlation with Foetal Outcome. Journal of the association of physicians of india. 2014,62:306-310.

17. Kanagal DV, Rajesh A, Rao K, Shetty H, Shetty PK, Ullal H. Zinc and copper levels in preeclampsia: a study from coastal South India. Int J Reprod Contracept Obstet Gynecol. 2014; 3(2): 370-373

18. Roberts JM, Balk JL, Bodner LM, Belizan JM, Berge E, Martinez A. Nutrient involvement in preeclampsia.2003; J Nutr; 133(55): 1684-92

19. Selina A, Shelina B, Sultana F. Calcium And Zinc Deficiency In Preeclamptic Women. J Bangladesh Soc Physiol. 2011 December; 6(2): 94-99.

20. He L, Lang L, Li Y, Liu Q, Yao Y. Comparison of serum zinc, calcium, and magnesium concentrations in women with pregnancy-induced hypertension and healthy pregnant women: A meta-analysis. Hypertens Pregnancy. 2016; 35(2):202-9.

21. Kumari B and Pankaj S. Evaluation of serum calcium and zinc in preeclamptic patients - a case control study. Global journal for research analysis. 2015;4,(9):113-114.

22. Vafaei H, Dalili M and Hashemi SA. Serum concentration of calcium, magnesium and zinc in normotensive versus preeclampsia pregnant women: A descriptive study in women of Kerman province of Iran. Iran J Reprod Med. 2015;13(1): 23-26.

23. K Vidhya. The role of serum calcium and zinc in pregnancy induced hypertension. TJPRC: International Journal of Pharmacology and Physiology. 2016; 2(1), 1-14. 